\title{
STUDI KUAT TARIK BETON \\ DENGAN MENGGUNAKAN AGREGAT KAYU KELAS I
}

STUDY OF CONCRETE PULL STRENGTH USING GRADE I WOOD AGGREGATE

\author{
Amir Mukhlis ${ }^{1}$ \\ ${ }^{1}$ Universitas Iskandarmuda, Kota Banda Aceh, Aceh, Indonesia. \\ E-mail: amirmukhlis@ @otmail.com
}

\begin{abstract}
ABSTRAK
Kegagalan struktur pada struktur beton akibat gempa adalah karena sifat material beton yang getas, kuat terhadap tarik namun lemah terhadap tekan sehingga bangunan dengan struktur beton akan lebih lemah terhadap bangunan struktur kayu. Saat terjadi gempa bumi, sebagian besar kegagalan bangunan terjadi pada struktur beton. Masalah getas tersebut tidak terjadi dengan material kayu sehingga bangunan dengan struktur kayu menjadi lebih aman ketika gempa. Kearifan lokal menjadi hal yang mendukung dalam menghadapi masalah gempa bumi. Penggunaan potongan kayu pada beton masih perlu dilakukannya kajian lebih mendalam. Pada penelitian ini direncanakan potongan kayu yang digunakan sebagai agregat kasar adalah kelas I berukuran $2 \mathrm{~cm}$ x $2 \mathrm{~cm}$ x $2 \mathrm{~cm}$ dengan rencana persentase penggunaan $40 \%, 50 \%$ dan $60 \%$. Potongan kayu dianalisis sifat fisisnya di laboratorium. Beton yang telah dicetak diuji kuat tarik belah pada umur 3, 7, dan 28 hari. Dari penelitian ini diharapkan dapat memberikan informasi tentang pengaruh penambahan potongan kayu sebagai agregat terhadap kuat tekan beton.
\end{abstract}

Kata Kunci: Kuat Tarik, Agregat, Kayu Kelas I.

\begin{abstract}
The failure of structures in concrete structures due to the earthquake is due to the brittle nature of the concrete material, which is strong against tension but weak against compression so that buildings with concrete structures will be weaker against wooden structures. During an earthquake, most building failures occur in concrete structures. This brittle problem does not occur with wood materials so that buildings with wooden structures are safer during an earthquake. Local wisdom is something that supports in dealing with earthquake problems. The use of wood chips in concrete still needs further study. In this study, it is planned that the pieces of wood used as coarse aggregate are grade I wood measuring $2 \mathrm{~cm} \times 2 \mathrm{~cm} \times 2 \mathrm{~cm}$ with a planned percentage of use of $40 \%$, $50 \%$ and $60 \%$. Wood chips are analyzed for physical properties in the laboratory. The molded concrete was tested for split tensile strength at the age of 3, 7, and 28 days. From this research is expected to provide information about the effect of adding pieces of wood as an aggregate on the compressive strength of concrete.
\end{abstract}

Keywords: Pull Strength, Aggregate, Grade I Wood. 


\section{PENDAHULUAN}

Propinsi Aceh merupakan kawasan yang terletak di antara pertemuan dua lempeng, yaitu lempeng Eurasia dan Indoaustralia. Akibat dari pertemuan lempeng ini, maka akan terjadi interaksi yang menyebabkan gempa bumi. Hal ini menjadikan Aceh menjadi lebih rawan terhadap gempa bumi karena insensitas kegempaanya yang cukup tinggi (Anonim, 2000). Hal ini telah terbukti, pada 26 Desember 2004 telah terjadi gempa bumi dengan magnitude 9,5 SR dan dilanjutkan dengan tsunami yang telah meratakan bangunan dengan tanah. Pada dasarnya, gempa bumi tidaklah membunuh orang, namun bangunanlah yang dapat membunuh orang karena kegagalan struktur bangunan.

Kegagalan struktur pada struktur beton akibat gempa adalah karena sifat material beton yang getas, kuat terhadap tekan namun lemah terhadap tarik sehingga bangunan dengan struktur beton akan lebih lemah terhadap bangunan struktur kayu. Saat terjadi gempa bumi, sebagian besar kegagalan bangunan terjadi pada struktur beton. Saat terjadinya gempa, masalah getas tersebut tidak terjadi dengan material kayu sehingga bangunan dengan struktur kayu menjadi lebih aman. Kearifan lokal menjadi hal yang mendukung dalam menghadapi masalah gempa bumi.

Untuk mengatasi sifat getas tersebut, beton diperkuat dengan tulangan baja sehingga menjadi struktur monolit. Dengan demikian tersusun pembagian tugas, dimana batang tulangan baja untuk memperkuat dan menahan gaya tarik, sedangkan beton hanya diperhitungkan untuk menahan gaya tekan (Dipohusodo, 1994). Sementara itu, penggunaan potongan kayu pada beton masih perlu dilakukannya kajian lebih mendalam dibandingkan penggunaan material baja. Dengan demikian, perlu dilakukannya kajian mengenai pengaruh penggunaan potongan kayu terhadap kekuatan beton. Kajian ini bertujuan untuk mengetahui bagaimana pengaruh penggunaan kayu kelas I terhadap kuat tarik beton.

\section{METODE PENELITIAN}

Penelitian ini dilakukan untuk mengetahui pengaruh penggunaan kayu kelas kuat I yang sesuai standar (BSN, 1994). terhadap kuat tekan dan kuat tarik belah beton normal. Beton direncanakan dengan variasi faktor air semen (FAS). Persentase penggunaan kayu yang direncanakan diambil dari volume beton. Sebagai pembanding dibuat beton normal dengan FAS di atas. Ukuran kayu yang digunakan adalah panjang $2 \mathrm{~cm}$, lebar $2 \mathrm{~cm}$ dan tinggi $2 \mathrm{~cm}$.

Data penelitian yang dikumpulkan meliputi data pemeriksaaan sifat-sifat fisis dan kimia agregat, pengujian berat volume agregat, pengujian slump, kadar udara dan berat volume. 
Di samping itu akan diuji kekuatan dan kekakuan beton muda pada umur 24 jam.

Material yang akan digunakan dalam penelitian ini adalah semen Portland tipe I yang umumnya banyak dipakai (BSN, 2004), agregat halus, air, serta kayu dengan ukuran yang telah dijelaskan sebelumnya. Menurut Mulyono (2005), pasta semen tidak bersifat elastis sempurna. Gaya gesek dalam, susut dan tegangan yang terjadi biasanya tergantung dari pemadatan dalam beton

Prosedur penelitian meliputi persiapan material, pemeriksaan agregat, perencanaan campuran beton (concrete mix design), pembuatan dan perawatan benda uji, serta pengujian benda uji. Beton segar dilakukan uji kelecakan beton (BSN, 1990).

\section{Pembuatan dan Perawatan Benda Uji}

Perencanaan proporsi campuran untuk benda uji pada penelitian ini didasarkan pada persentase potongan kayu sebanyak persentase dari volume beton dengan FAS tertentu (BSN, 1993). Variasi dan jumlah benda uji untuk pengujian kuat tarik belah digunakan dalam penelitian. Sebagai pembanding dibuat benda uji untuk masing-masing jenis pengujian tanpa menggunakan material kayu.

Benda uji untuk pengujian tekan adalah silinder standar dengan diameter $15 \mathrm{~cm}$ dan tinggi $30 \mathrm{~cm}$ yang diuji pada umur beton 3,7 dan 28 hari. Benda uji tekan silinder dengan diameter $15 \mathrm{~cm}$ dan tinggi $30 \mathrm{~cm}$ juga digunakan untuk perhitungan energi kehancuran sebagai indikator daktilitas beton. Temperatur air pengaduk beton menurut Anonim (1995) tidak boleh lebih dari $23{ }^{\circ} \mathrm{C}$. Temperature kamar dan material beton berkisar antara $20^{\circ} \mathrm{C}$ s.d $27^{\circ} \mathrm{C}$. Anonim (1991) menyatakan suhu mortar maksimum $32^{\circ} \mathrm{C}$.

\section{Pengujian Kuat Tarik Belah Beton}

Kekuatan tarik belah beton relatif rendah. Nilai kuat tekan dan tarik bahan beton tidak berbanding lurus, setiap usaha perbaikan mutu kekuatan tekan hanya disertai peningkatan kecil nilai kuat tariknya. Suatu perkiraan kasar dapat dipakai, bahwa nilai kuat tarik bahan beton normal hanya berkisar antara 9\%- 15\% dari kuat tekannya. Kuat tarik bahan beton yang tepat sulit untuk diukur. Suatu nilai pendekatan yang umum dilakukan dengan menggunakan modulus of rupture, ialah tegangan tarik lentur beton yang timbul pada pengujian hancur balok beton polos (tanpa tulangan), sebagai pengukur kuat tarik sesuai teori elastisitas.

Kuat tarik belah bahan beton juga ditentukan melalui pengujian split cylinder yang umumnya memberikan hasil yang lebih baik dan lebih mencerminkan kuat tarik sebenarnya. Nilai pendekatan yang diperoleh dari hasil pengujian berulang kali mencapai kekuatan $0,50-0,60$ kali $\sqrt{ } \mathrm{fc}^{\prime}$ sehingga untuk beton normal digunakan nilai $0,57 \sqrt{ }$ fc. 
Pengujian tersebut menggunakan benda uji silinder beton berdiameter $150 \mathrm{~mm}$ dan panjang $300 \mathrm{~mm}$, diletakkan pada arah memanjang atas alat penguji kemudian beban tekan diberikan merata arah tegak dari atas pada seluruh panjang silinder. Apabila kuat-tarik terlampaui, benda uji terbelah menjadi dua bagian dari ujung ke ujung. Tegangan tarik yang timbul sewaktu benda uji terbelah menjadi dua disebut sebagai split clinder strength, diperhitungkan sebagai berikut :

$$
f_{t}=\frac{2}{\pi}
$$

$$
\frac{P}{L D}
$$

di mana,

$\mathrm{ft}=$ kuat tarik belah $\left(\mathrm{N} / \mathrm{m}^{2}\right)$

$\mathrm{p}=$ beban pada waktu belah $(\mathrm{N})$

$\mathrm{L}=$ panjang benda uji silinder $(\mathrm{m})$

$\mathrm{D}=$ diameter benda uji silinder $(\mathrm{m})$

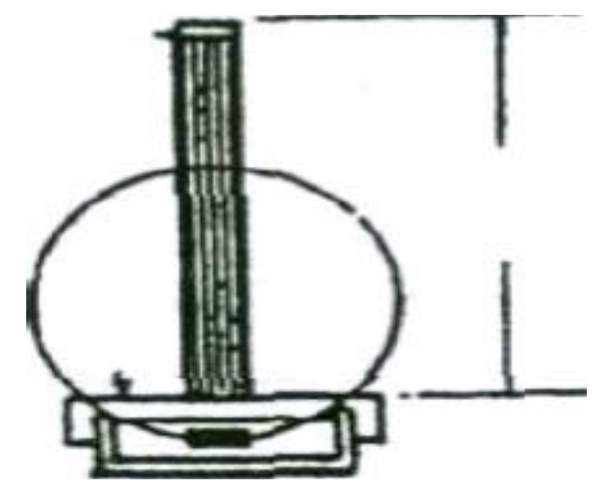

Gambar 1. Sketsa Pengujian tarik belah beton Sumber: BSN (2002) ${ }^{11}$

HASIL PENELITIAN DAN PEMBAHASAN

\section{Pemeriksaan Sifat-sifat Fisis Agregat}

Pemeriksaan sifat-sifat fisis agregat ini dilakukan terhadap agregat kasar (kerikil), agregat halus (pasir). Adapun Pemeriksaan sifat-sifat fisis agregat meliputi pemeriksaan berat jenis (specific gravity), kadar air agregat (moisture content), penyerapan (absorbs), Modulus kehalusan (fineness modulus), kadar lumpur, susunan butiran (sieve analysis).

1.1 Berat jenis (specific gravity) dan penyerapan (absorbsion)

Hasil perhitungan berat jenis dapat dilihat pada tabel 1 .

Tabel 1. Hasil perhitungan berat jenis agregat

\begin{tabular}{|l|l|c|c|}
\hline \multirow{2}{*}{ No. } & \multirow{2}{*}{ Jenis Agregat } & \multicolumn{2}{|c|}{ Berat Jenis } \\
\cline { 3 - 4 } & & $\mathbf{S g}_{\text {ssd }}$ & $\mathbf{S g}_{\text {od }}$ \\
\hline 1. & Kerikil & 2,73 & 2,71 \\
\hline 2. & Pasir & 1,67 & 1,58 \\
\hline 3 & Kayu Kelas I & 1,13 & 1,06 \\
\hline
\end{tabular}

Berdasarkan tabel 1 dapat dijelaskan bahwa, berat jenis agregat yang digunakan sebagai material campuran beton baik dan untuk berat jenis pasir kering jenuh permukaan tidak sesuai dengan teori yang ditetapkan oleh Troxell (1968) ${ }^{14}$ tetapi agregat halus masih dapat digunakan dan untuk kerikil juga sudah memenuhi syarat, sedangkan berdasarkan pendapat Orchard $(1979)^{5}$, nilai berat jenis agregat tersebut sudah memenuhi syarat yang telah ditentukan, yaitu kerikil antara 2,6-2,7 dan 
pasir lebih besar dari pada 2,6. Berdasarkan SNI 03-3527-1994 untuk kayu kelas I sudah memenuhi syarat yang telah ditentukan.

Hasil persentase dari perhitungan berat jenis agregat jenuh air kering permukaan (SSD) dengan berat jenis agregat kering oven (OD), maka diperoleh nilai penyerapan (absorption) agregat, yaitu agregat kasar (kerikil), agregat halus (pasir). Hasil perhitungan penyerapan agregat tersebut dapat dilihat pada tabel 2.

Tabel 2 Hasil perhitungan penyerapan agregat

\begin{tabular}{|c|l|c|}
\hline No. & \multicolumn{1}{|c|}{ Jenis Agregat } & $\begin{array}{c}\text { Penyerapan } \\
(\%)\end{array}$ \\
\hline 1. & Kerikil (coarse agregat) & 0,625 \\
\hline 2. & Pasir (find sand) & 6,38 \\
\hline
\end{tabular}

Berdasarkan Tabel 2 di atas, nilai persentase penyerapan agregat untuk kerikil memenuhi persyaratan yang telah ditentukan Troxell $(1968)^{14}$ yaitu antara 0,5\%-1\%. Untuk pasir tidak memenuhi syarat yaitu antara $0 \%$ $2 \%$. Tetapi nilai agregat yang lebih besar dari persyaratan tetap dipakai.

\subsection{Kadar air agregat (moisture content)}

Hasil perhitungan kadar air untuk agregat halus dapat dilihat pada tabel 3.

Tabel 3. Hasil perhitungan kadar air agregat

\begin{tabular}{|c|c|c|}
\hline No. & Jenis Agregat & Kadar air \\
& & $(\%)$ \\
\hline
\end{tabular}

\begin{tabular}{|c|l|c|}
\hline 1. & Kerikil (coarse agregat) & SSD 3,51 \\
\hline 2. & Pasir (find sand) & SSD 1,4 \\
\hline 3. & Kayu Kelas I & 11,97 \\
\hline
\end{tabular}

Berdasarkan tabel 3 di atas, nilai presentase kadar air normal agregat halus memenuhi persyaratan yang telah ditentukan yaitu lebih kecil dari 6,5\%, sedangkan untuk agregat kasar tidak memenuhi persyaratan yang telah ditentukan yaitu lebih besar dari $1,04 \%$. Dengan diketahuinya kadar air, maka air campuran beton dapat disesuaikan agar faktor air semen (water cement ratio) yang diambil konstan. Sedangkan untuk kayu, kadar air kayu memenuhi persyaratan untuk penggunaan sebagai bahan kontruksi bangunan yaitu lebih kecil dari pada $23 \%$.

\subsection{Kadar lumpur agregat}

Hasil perhitungan kadar lumpur untuk agregat halus dan agregat kasar dapat dilihat pada tabel 4.

Tabel 4. Hasil perhitungan kadar lumpur agregat

\begin{tabular}{|c|c|c|c|}
\hline \multirow[b]{2}{*}{ No. } & \multirow[b]{2}{*}{ Jenis Agregat } & \multirow{2}{*}{$\begin{array}{c}\text { Kadar } \\
\text { lumpur } \\
(\%)\end{array}$} & Teori \\
\hline & & & SNI 03-1750-1990 \\
\hline 1. & $\begin{array}{l}\text { Kerikil (coarse } \\
\text { agregat) }\end{array}$ & 1,92 & $<1 \%$ \\
\hline 2. & Pasir (find sand) & 1,3 & $<5 \%$ \\
\hline
\end{tabular}

Berdasarkan tabel 4 di atas, nilai persentase kadar lumpur agregat untuk agregat kasar tidak memenuhi persyaratan yang telah ditentukan SNI 03-1750-1990 (1990) ${ }^{7}$, yaitu 
lebih besar dari $1 \%$. Sedangkan untuk agregat halus telah memenuhi persyarat yaitu lebih kecil dari $5 \%$. Tetapi nilai kadar lumpur agregat kasar yang lebih besar dari persyaratan tetap dipakai dengan catatan dicuci dahulu sebelum digunakan untuk campuran beton.

\subsection{Susunan butiran (gradasi agregat)}

Pemeriksaan agregat dengan menganalisis susunan butiran, maka dapat diketahui gradasi agregat yang digunakan sebagai material pembentuk beton apakah termasuk golongan material yang baik. Grafik pada penelitian ini menjelaskan bahwa, gradasi yang diperoleh adalah gradasi menerus (continous grade) karena butir agregat yang digunakan pada semua ukuran saringan, butirnya lengkap dan terdistribusi dengan baik.

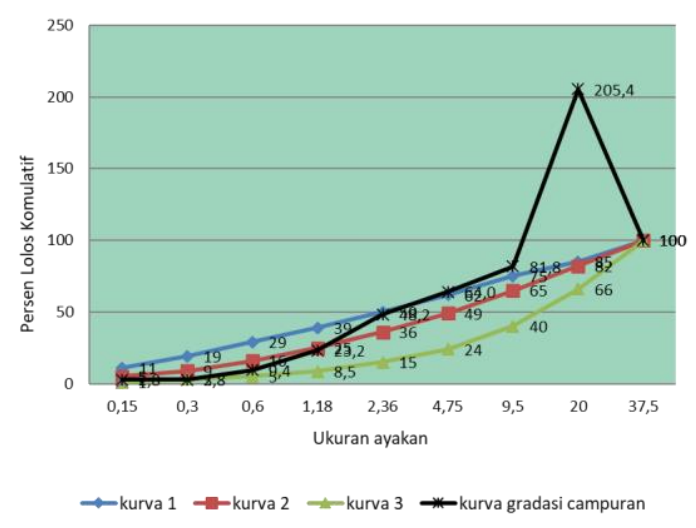

Gambar 2. Grafik gradasi susunan butiran campuran agregat

Berdasarkan gradasi tersebut dapat diketahui letak kurva gradasi agregat yang baik pada daerah yang disyaratkan, yaitu berada pada daerah (3) sesuai dengan persyaratan untuk material pembentuk beton.

Pengujian kuat tekan dilakukan pada benda uji saat beton berumur 3, 7, dan 28 hari. Pengujian kuat tarik belah beton dengan cara memberikan beban arah horizontal sejajar dengan diameter benda uji.

\section{Hasil Pengujian Kuat Tarik Belah Beton}

Sebelum dilakukan pengujian benda uji yang akan diuji terlebih dahulu dikeluarkan dari tempat perawatan, dibersihkan dari kotoran yang menempel, ditimbang beratnya dan diukur dimensinya $(\mathrm{BSN}, 1990)^{10}$.

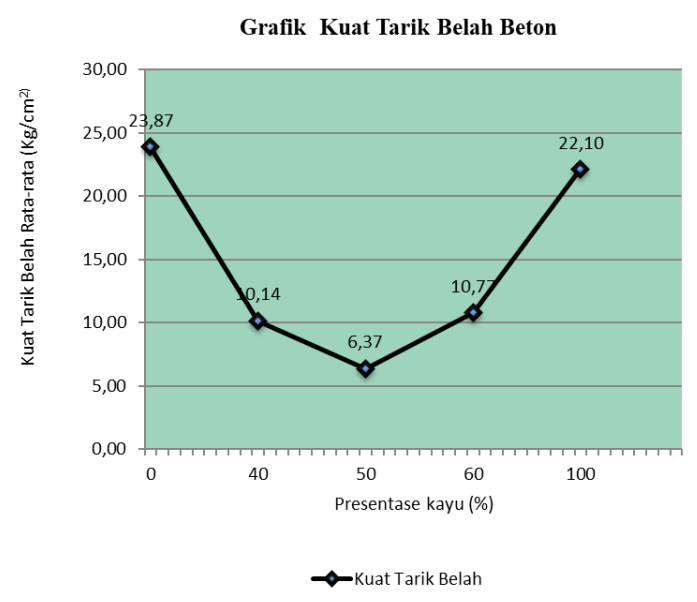

Gambar 3. Grafik kuat tarik belah beton

Berdasarkan gambar 3, hasil pengujian kuat tarik belah dapat disimpulkan bahwa telah terjadi penurunan kuat tarik belah beton pada beton yang menggunakan kayu kelas kuat I sebagai pengganti agregat kasar seragam. Hasil rata-rata pengujian kuat tarik belah beton, yaitu 
untuk beton normal adalah $23,87 \mathrm{~kg} / \mathrm{cm}^{2}$, beton dengan campuran $40 \%$ kayu adalah 10,14 $\mathrm{kg} / \mathrm{cm}^{2}$ atau $42,5 \%$ dari beton normal, beton dengan campuran $50 \%$ kayu adalah $6,37 \mathrm{~kg} / \mathrm{cm}^{2}$ atau $26 \%$ dari beton normal, beton dengan campuran $60 \%$ kayu adalah $10,77 \mathrm{~kg} / \mathrm{cm}^{2}$ atau $45 \%$ dari beton normal dan pada beton dengan campuran kayu 100\% menunjukkan penurunan yang tidak begitu besar yaitu $22,10 \mathrm{~kg} / \mathrm{cm}^{2}$ atau $92,6 \%$ dari beton normal.

Tabel 5. Presentase kuat tarik belah beton kayu terhadap beton normal

\begin{tabular}{|c|c|c|}
\hline $\begin{array}{c}\text { Nama } \\
\text { Benda } \\
\text { Uji }\end{array}$ & $\begin{array}{c}\text { Kuat Tarik } \\
\left(\mathrm{f}^{\prime} \mathrm{t}\right)\end{array}$ & $\begin{array}{c}\text { Presentase } \\
(\%)\end{array}$ \\
\hline BN 1 & 23.87 & 100.0 \\
\hline BKV 2 & 10.14 & 42.5 \\
\hline BKV 3 & 6.37 & 26.7 \\
\hline BKV 4 & 10.77 & 45.1 \\
\hline BKV 5 & 22.10 & 92.6 \\
\hline
\end{tabular}

\section{KESIMPULAN}

1. Kayu kelas kuat I dapat digunakan untuk campuran beton, tetapi beton yang dihasilkan tidak dapat digunakan sebagai komponen struktur.

2. Pengaruh kuat tekan beton terhadap penambahan kayu kelas kuat I adalah semakin banyak penambahan kayu pada campuran pembentuk beton, semakin besar hasil kuat tekan yang di peroleh walaupun tidak mendekati kuat tekan yang direncanakan ini disebabkan beton tidak melekat sempurna dengan agregat kasar.

3. Pada penambahan campuran kayu menghasilkan mutu pelaksanaan beton yang tidak jauh berbeda dari keadaan beton normal termasuk sangat baik sampai dengan sedang. 


\section{DAFTAR PUSTAKA}

1. Annual Book of ASTM Standard 1995, Section 4, Volume 04.02, Concrete and Aggregates, International Standard-Worldwide.

2. Departemen Pekerjaan Umum. LPMB, 1991, Tata Cara Rencana Pembuatan Campuran Beton Normal, SK SNI T-15-1990-03, Cetakan pertama, Bandung: DPU-Yayasan LPMB.

3. Dipohusodo, I., 1999, Struktur Beton Bertulang Berdasarkan SK SNI T-15-1991-03 Departemen Pekerjaan Umum RI, Penerbit Gramedia Pustaka Utama, Jakarta.

4. Mulyono, T., 2005, Teknologi Beton, Penerbit Andi Yogyakarta.

5. Orchard, A.M., 1979, Concrete Technology Properties of Material, Applied Science Publishers Limited, London.

6. SNI 03-1726-2000, Wilayah Gempa di Indonesia.

7. SNI 03-1750-1990, Metode Pengujian Material Bahan Bangunan Bukan Logam.

8. SNI 03-3527-1994, Mutu dan Ukuran Kayu Bangunan.

9. SNI 03-1972-1990, Metode Pengujian Slump Beton.

10. SNI 03-1974-1990, Metode Pengujian Kuat Tekan Beton.

11. SNI 03-2491-2002, Metode Pengujian Kuat Tarik Belah Beton.

12. SNI 03-2834-1993, Tata Cara Pembuatan Rencana Campuran Beton Normal.

13. SNI 15-2049-2004, Semen Portland.

14. Troxel, 1986, Concrete Technology Properties of Material, London. 